„TURYZM" 1995, t. 5, z. 2

\title{
Antoni Jackowski
}

\section{PROFESOR JADWIGA WARSZYŃSKA - BADACZ I NAUCZYCIEL AKADEMICKI}

\author{
LE PROFESSEUR JADWIGA WARSZYŃSKA - \\ CHERCHEUR ET PROFESSEUR ACADÉMIQUE \\ PROFESSOR JADWIGA WARSZYŃSKA - \\ A RESEARCHER AND ACADEMIC TEACHER
}

Prof. zw. dr hab. Jadwiga Warszyńska (córka Antoniny i Stanisława Szymańskich) urodziła się 18 lipca $1925 \mathrm{r}$. w Tarnowie w rodzinie nauczycielskiej. Studia wyższe odbyła w latach 1947-1952 na Wydziale Matematyczno-Przyrodniczym Uniwersytetu Jagiellońskiego uzyskując stopień magistra fílozofii (tytuł pracy magisterskiej: Więź przestrzenno-spoleczna w Krakowie). Stopień naukowy doktora nauk przyrodniczych nadała Jej w 1961 r. Rada Wydziału Biologii i Nauk o Ziemi UJ na podstawie rozprawy pt. Rozwój sieci komunikacyjnej w województwie krakowskim. Stopień doktora habilitowanego nadała Jej ta sama Rada Wydziału w 1974 r. (tytuł rozprawy habilitacyjnej: Ocena zasobów środowiska naturalnego dla potrzeb turystyki). Tytuł profesora nadzwyczajnego uzyskała w 1983 r., zaś profesora zwyczajnego w 1989 r.

Profesor Jadwiga Warszyńska pracowała w latach 1951-1954 jako nauczycielka Liceum Pedagogicznego w Tarnowie, następnie od 1954 do 1958 r. odbywała studia aspiranckie - najpierw przy Uniwersytecie Warszawskim, później przy Uniwersytecie Jagiellońskim. Od 1958 r. pracuje nieprzerwanie jako nauczyciel akademicki i badacz w Instytucie Geografii Uniwersytetu Jagiellońskiego (1958-1961 asystent, 1961-1964 starszy asystent, 1964-1976 adiunkt, 1976-1983 docent, 1983-1989 profesor nadzwyczajny, od 1989 r. profesor zwyczajny).

Opublikowany dorobek obejmuje łącznie blisko 100 pozycji. Na Jej dorobek naukowy składają się również liczne prace nie publikowane (studia, analizy, opracowania metodyczne) wykonane na zlecenie instytucji naukowych i administracji państwowej. 
Przedmiotem badań prof. J. Warszyńskiej w początkowym okresie Jej działalności naukowej była geografia transportu i usług. Problematyki tej dotyczy szereg studiów regionalnych o charakterze analitycznym (w tym również rozprawa doktorska), a także opracowań syntetycznych zmierzających do typologii i klasyfikacji przestrzennej. Prace te posiadają walor metodyczny, zawierają bowiem próby zastosowań wprowadzanych wówczas do badań z zakresu geografii społeczno-ekonomicznej metod statystycznych, zwłaszcza metod koncentracji i taksonomii numerycznej.

Od drugiej połowy lat 60. do chwili obecnej, główną dziedziną zainteresowań jest geografia turyzmu. Należą tu liczne opracowania monograficzne obszarów byłego województwa krakowskiego oraz miasta Krakowa. Na szczególną uwage zasługują zwłaszcza studia teoretyczno-metodologiczne, które odnoszą się zarówno do teorii geografii turyzmu jako młodej dyscypliny geograficznej, jak i do konkretnych rozwiazzań metodologicznych. Te ostatnie dotyczyły najczęściej ilościowej oceny zasobów środowiska przyrodniczego dla potrzeb turystyki. Do nich należy też praca habilitacyjna, w której Autorka przedstawiła propozycję metody, polegającej na zastosowaniu modelu matematycznego do oceny atrakcyjności poszczególnych elementów środowiska w skali miejscowości. Metoda, referowana kilkakrotnie na spotkaniach międzynarodowych, znalazła zastosowanie w praktyce. Jej nieco odmienna wersja posłużyła również do określenia zasad oceny atrakcyjności podmiejskich stref rekreacyjnych (Kongres MUG w Moskwie).

Charakter metodyczny mają również prace dotyczące prognozowania ruchu turystycznego. Zagadnienia teoretyczne zostały usystematyzowane w publikacji typu podręcznikowego Podstawy geografii turyzmu (z A. Jackowskim). Studia teoretyczno-metodologiczne, stale pogłębiane, stały się podstawowymi w literaturze polskiej (i nie tylko!) pracami rozszerzającymi naszą wiedzę o istocie geografii turyzmu, odegrały też one ważną rolę $w$ badaniach nad możliwościami i kierunkami rozwoju turystyki, zwłaszcza na obszarach górskich i wyżynnych.

Przedstawiona w latach 80 . zmodyfikowana koncepcja geografii turyzmu, o rozszerzonym polu badawczym, spotkała się z zainteresowaniem ośrodków zagranicznych, czego dowodem było zlecenie przez Komisję Geografii Turyzmu Międzynarodowej Unii Geograficznej (MUG) opracowanie odpowiedniej informacji (publikacja w czasopiśmie „GeoJournal”). Kontynuując i rozwijając podejmowaną wcześniej problematykę przedstawiła również zasady systemowych badań prognostycznych ruchu turystycznego (Kongres MUG w Paryżu).

Duży udział w twórczości naukowej ostatniego okresu mają także opracowania regionalne, w których przeważają ujęcia kompleksowe $\mathrm{z}$ uwzględnieniem podstaw historycznych, a także problematyki wchodzącej w zakres geografii kultury. Syntezą regionalna jest $\mathrm{m}$. in. studium o charakterze metodycznym, które zawiera próbę określenia stopnia rozwoju funkcji turystycznej polskich 
Karpat. Inny typ reprezentują opracowania regionalne, ukierunkowane na problem zróżnicowania pod względem skuteczności wypoczynku konkretnych środowisk przyrodniczych, a także przemian atrakcyjności pod wpływem inwestycji $w$ budownictwie wodnym.

Do działalności popularyzatorskiej należy zaliczyć opracowanie licznych haseł o tematyce komunikacyjnej i turystycznej do słowników (WSP 1982, PWN 1983), a także map do atlasów wojewódzkich (krakowskiego 1979, bielskiego 1981, tarnowskiego 1988) i m. Krakowa (1988).

Odrębną sferą działalności naukowej prof. Jadwigi Warszyńskiej jest Jej udział jako inspiratora i organizatora badań i opracowań zbiorowych, zarówno o charakterze monografii regionalnych, jak i podręczników akademickich. Znaczącą pozycję, której była redaktorem i współautorem, zajmuje obszerne studium monograficzne Województwo tarnowskie (Ossolineum 1988). Szczególne miejsce w Jej dorobku zajmuje dwutomowy podręcznik Geografia turystyczna świata (PWN 1994, 1995). Dzieło to powstało z inspiracji prof. J. Warszyńskiej, Ona też je redagowała. Prace nad tym podręcznikiem trwały od 1983 r. Pierwsza wersja ukazała się w formie skryptu Uniwersytetu Jagiellońskiego $(1988,1989)$. Geografia turystyczna świata jest pierwszym w światowej literaturze przedmiotu podręcznikiem o tak szerokim zakresie merytorycznym. Profesor Jadwiga Warszyńska kieruje również pracami nad całościową Monografiq turystyczna Karpat, z której pierwsza część, dotycząca Karpat Rumuńskich, ukazała się w 1988 r. Redagowała też część pt. Stosunki spoleczno-ekonomiczne w Monografii dorzecza górnej Wisty. W połowie 1995 r. ukazała się redagowana przez Nią monografia Karpat (tytuł: Karpaty Polskie - przyroda, czlowiek i jego dziatalność). W tym przypadku inspiratorem i autorem koncepcji opracowania była prof. J. Warszyńska. Również ta pozycja stanowić będzie pierwszą w literaturze tak obszerną monografię Karpat. Upór i konsekwencja działania prof. J. Warszyńskiej w pokonywaniu trudności związanych z publikacja, Jej wielki autorytet naukowy pozwoliły pokonać przeszkody, łącznie z kłopotami natury finansowej. Na Jej apel o finansowanie pozycji odpowiedziało szereg instytucji i fundacji. Bez przesady można powiedzieć, że ta monografia jest w całości Jej dziełem, mimo, że skupiła ona kilkudziesięciu autorów. Jest to również bez wątpienia najważniejsze kompleksowe opracowanie Karpat, jakie ukazało się w bieżącym stuleciu.

Dla pełnego obrazu osiagnięć prof. J. Warszyńskiej w zakresie prac redakcyjnych należy wymienić Jej projekt wydawniczy Atlasu turystyki Polski (zaniechany niestety z przyczyn natury finansowej). Jest też redaktorem „Zeszytów Naukowych UJ. Prac Geograficznych" (seria Geografia Ekonomiczna). Uczestniczy w pracach Komitetów Redakcyjnych wielu wydawnictw, m. in. „Folia Geographica. Series Geographica-Oeconomica", (Komisja Nauk Geograficznych Oddział PAN w Krakowie), „Turyzm” (Uniwersytet Lódzki), jest także członkiem Komitetu Programowego „Problemów Turystyki” (Instytut Turystyki). 
Jako geograf turyzmu prof. J. Warszyńska zajmuje w kraju pozycję pionierską, ma również uznanie za granicą. Prace Jej cytowane są przez różnych autorów. Od 1973 r. była członkiem Grupy Roboczej Geografii Turyzmu Międzynarodowej Unii Geograficznej, w 1980 r. została mianowana członkiem - utworzonej w miejsce Grupy Roboczej - Komisji. Uczestniczyła czynnie w Międzynarodowych Kongresach MUG (Moskwa 1976, Paryż 1984), sympozjach; była współorganizatorem sympozjum w Polsce (1974). Brała udział w pracach Komisji, m. in. w tematach "Problemy badawcze i metody w geografii turyzmu”, „Kartografia turystyczna”.

W ciagu swojej 30-letniej praktyki dydaktyczno-wychowawczej, prof. J. Warszyńska prowadziła wszelkie typy zajęć z zakresu geografii społeczno-ekonomicznej, regionalnej, a także statystyki i ekonometrii. Poprzez swoje osobiste zaangażowanie przyczyniła się w dużym stopniu do utworzenia w $1977 \mathrm{r}$. w Instytucie Geografii UJ pierwszej wówczas w Polsce specjalności dydaktycznej z geografii turyzmu. Od tego też czasu Jej praca dydaktyczna koncentruje się głównie na przedmiotach tej specjalności. Pod Jej kierunkiem w latach 1977-1995 dyplom magistra uzyskało około 250 absolwentów. Prace magisterskie przekazywane były wielokrotnie zainteresowanym instytucjom dla celów praktycznych.

Była promotorem 3 doktorów, a także opiekunem 3 przewodów habilitacyjnych. Spośród Jej uczniów dwie osoby uzyskały już stopień doktora habilitowanego, a jedna osoba - stopień doktora habilitowanego i tytuł profesora.

Przez 10 lat (1974-1984) prof. J. Warszyńska pełniła funkcję zastępcy dyrektora Instytutu Geografii UJ, w tym przez 7 lat (1974-1981) ds. dydaktyczno-wychowawczych. W latach 1979-1984 była członkiem Zespołu Dydaktyczno-Wychowawczego przy MNSzWiT. Od 1979 r. do 1994 r. była kierownikiem Zakładu Geografii Turyzmu. W ramach działalności UJ na rzecz gospodarki narodowej była pełnomocnikiem ds. porozumienia między Uniwersytetem Jagiellońskim a Ministerstwem Komunikacji. Prowadzi rozległą współpracę $\mathrm{z}$ innymi uczelniami, Polską Akademią Nauk, instytucjami resortowymi, a także organizacjami społecznymi i urzędami administracji państwowej.

Należy do Komisji Nauk Geograficznych Oddziału PAN w Krakowie, jest członkiem Rady Naukowej Instytutu Turystyki oraz zespołu doradczego tegoż Instytutu. Wchodziła w skład zespołów doradczych przy Wojewódzkim Urzędzie Statystycznym w Krakowie, Biurze Rozwoju Krakowa, Urzędzie Wojewódzkim w Nowym Sączu. Pracowała społecznie w Polskim Towarzystwie Geograficznym jako przewodnicząca Komisji Geografii Turyzmu (1977-1993).

Za działalność naukową otrzymała dwie Nagrody Ministerstwa NSzWiT: trzeciego stopnia za pracę habilitacyjna, drugiego stopnia za podręcznik Podstawy geografii turyzmu (z A. Jackowskim) oraz nagrodę Zespołową Ministerstwa Edukacji Narodowej I stopnia za współudział w opracowaniu Atlasu miasta Krakowa (1989). Za osiagnięcia naukowe, dydaktyczno-wychowawcze oraz 
za koordynację porozumień z jednostkami gospodarki narodowej była wielokrotnie wyróżniana Nagrodami Rektora UJ.

Z odznaczeń państwowych posiada Złoty Krzyż Zasługi (1976) oraz Krzyż Kawalerski Orderu Odrodzenia Polski (1984). Za działalność w Polskim Towarzystwie Geograficznym otrzymała Złotą Odznakę PTG (1985).

Zarysowane powyżej osiagnięcia naukowe i dydaktyczne dobitnie świadczą o wielkim wkładzie prof. Jadwigi Warszyńskiej w naukę polską. Jest Ona niekwestionowanym w gronie geografów twórcą współczesnych badań w zakresie geografii turyzmu. Jej inicjatywy przyciagają do utworzonego przez Nią Zakładu Geografii Turyzmu wiele osób z różnych ośrodków naukowych w Polsce i z zagranicy. Wszystkich gości prof. Jadwiga Warszyńska zawsze podejmuje niezwykle serdecznie. Te liczne wizyty z pewnością sankcjonują niejako bezsporny fakt wykształcenia się - dzięki Profesor Jadwidze Warszyńskiej - krakowskiej szkoły w dziedzinie geografii turyzmu.

Prof. dr hab. Antoni Jackowski

Wpłynęło:

Instytut Geografii

21 października $1995 \mathrm{r}$.

Uniwersytet Jagielloński

ul. Grodzka 64

31-044 Kraków 